\title{
Sustainable Development: A Soft Law Concept Transforming SD- Oriented Initiatives of the UN System into Hard Law Instruments in UN Member-states and Promoting Partnerships Around the Globe
}

\author{
Edward T. Bristol-Alagbariya* \\ Associate Dean \& Senior Multidisciplinary Lecturer, Faculty of Law, University of Port Harcourt, NIGERIA; \\ Affiliate Visiting Fellow, University of Aberdeen, UNITED KINGDOM; and Visiting Research Fellow, Centre \\ for Energy, Petroleum \& Mineral Law and Policy (CEPMLP), Graduate School of Natural Resources Law, \\ Policy \& Management, University of Dundee, Scotland, UNITED KINGDOM
}

\begin{abstract}
This study examines the subject-matter of Sustainable Development (SD) as a soft law concept, which is transforming SD-oriented initiatives of the UN and beyond into hard law instruments in sovereign states of the world, which are UN member-states. It demonstrates that in the process, SD-oriented initiatives, which are increasingly being backed by law in sovereign states, are promoting and enhancing partnerships towards SD in the nooks and crannies of these states. Its aim is to underscore the significance of ongoing global efforts, which are designed to promote the achievement of $\mathrm{SD}$, and how the private sector, peoples, communities, countries, regions and entire global community are taking advantage of the fruits of these ongoing efforts to enter into or consummate various forms of SD-oriented partnership relationships. The study thus exemplifies various forms of partnerships being arrived at in the global march towards SD, as these arrangements go beyond those which are entered into on the platform of the UN, to many more which, consequent upon the continuing UN Conferences aimed at fostering and enhancing SD, are being entered into between and among many domestic and international entities, such as between and among local communities, the private sector, such as multinational companies (MNCs), and relevant institutions and agencies of host governments, as well as bilateral, regional and other international groups and oganisations. These include partnerships between and among entities of the Global South-South and the Global North-South, as well as Public Private Sector Partnerships (PPSPs) between host governments of developing countries, advanced countries, developmental agencies of advanced countries and MNCs, for various forms of development and SD plans, policies and programmes (including projects (PPPs) in developing countries. While underscoring the significant, key, compelling and inevitable roles of public sector governance, especially Government Social Responsibility (GSR), embedded in good, transparent, accountable and responsible political leadership [good governance: GG]), the study advocates and recommends the need for more and more SD-oriented partnership arrangements around the world, in the course of ongoing global efforts to promote and achieve SD, so as to secure the wellbeing of humans and overall nature, towards a fairer, kinder, more just, sustainable and peaceful existence on Planet Earth.

Keywords: Sustainable Development (SD); Business Sustainability; Government Social Responsibility (GSR); Corporate Social Responsibility (CSR); SD-oriented Partnerships; Plans, Policies and Programmes (including Projects (PPPs); Public Private Sector Partnerships (PPSPs); Stockholm, Rio, Johannesburg and Rio (SRJR) Process; Good Governance (GG); Wellbeing; and Planet Earth.
\end{abstract}

DOI: $10.7176 / \mathrm{JLPG} / 94-06$

Publication date: February $29^{\text {th }} 2020$

\section{Introduction}

This study will concentrate on the concept of sustainable development (SD) and the UN system, with emphasis on the history of SD in the context of the UN system and the precise outcomes of successive ongoing Conferences of the UN towards achieving SD.

The UN is, no doubt, a platform and sound basis to consider the history and ongoing global efforts and trends towards achieving SD. However, the term SD, associated with sustainability, may be traced to Robert PrescottAllen, of the World Conservation Strategy (WCS) and the Expert Group for SD indicators (SDIs) on the UN Commission on SD. Prescott-Allen was a staff-writer for the International Union for Conservation of Nature (IUCN - i.e., the World Conservation Union) and principal author of the WCS. ${ }^{1}$ The WCS is a landmark publication of 1980 that helped to define the concept of SD and thereby shaped global outlook on conservation and SD. Prescott-Allen introduced the term 'sustainable development' and promoted the preparation of National Conservation Strategies (NCSs), in the process of which he linked the wellbeing of countries to the wellbeing of

${ }^{1}$ The International Union for Conservation of Nature (i.e., the World Conservation Union [IUCN]) et al, World Conservation Strategy: Living Resource Conservation for Sustainable Development (IUCN 1980). 
people and a healthy environment in the countries. Prescott-Allen's approach and analysis demonstrate that there is a nexus between the wellbeing of countries and the wellbeing of people and the environment (and by extension the wellbeing of ecology, ecosystems and ecosystem services) within countries. ${ }^{1}$

Sustainability and SD eventually came into prominence as an outcome of the establishment of the World Commission on Environment and Development (WCED) by the UN. This Commission, chaired by a former Norwegian Prime Minister and former Director-General of the World Health Organisation (WHO), Dr Gro Harlem Brundtland, was set-up in 1983, as an independent body, after the UN Stockholm Conference on the Human Environment of 1972. It was set-up to address increasing global concerns about the accelerating deterioration of the human environment and natural resources and the consequences of such deterioration on socio-economic development and all-inclusive prosperity associated with the growth and advancement of peoples and countries around the globe. ${ }^{2}$ Interestingly, while setting-up the Commission, the UN recognised that environmental problems were global in nature, and that it is in the common interest of all nations to establish policies and to embark on actions for SD. ${ }^{3}$ The brief of the Commission was thus to re-examine the critical environment and development problems on Planet Earth and to formulate realistic proposals to solve such problems, so as to ensure sustainable human progress through development, without endangering the environment and bankrupting the resources of future generations. The Commission was to investigate the numerous concerns of previous decades, namely, that human activity was having severe and negative impacts on the planet, and that patterns of growth and development would be unsustainable, if they continued unchecked. ${ }^{4}$

Consequently, the WCED came into being in the UN system as a result of ongoing global efforts to achieve $\mathrm{SD}$, which are dynamically being championed, spearheaded and midwifed by the UN, in the course of the UN Conferences on the environment and development, which are designed to promote the achievement of SD. These UN Conferences began with the Conference on the Human Environment (UNCHE), held at Stockholm, Sweden, in 1972, which marked the first globalised step to initiate action plans and strategies towards a more sustainable pattern of development, as it examined and focussed on the irrefutable fact and evidences that development and the environment, which were hitherto addressed as separate issues, could be managed in a mutually beneficial way. It was at this Conference that the concept of SD was first formerly recognised by the entire global community. ${ }^{5}$ Following the Stockholm UNCHE, the assembly of the world community leaders from the UN member-states took place in Nairobi, Kenya, from 10 - 18 May 1982. The rest of the UN Conferences organised so as to achieve SD are the Conference on Environment and Development (UNCED), which is informally known as the 'Earth Summit', held at Rio de Janeiro, Brazil, in 1992; the World Summit on SD (WSSD), held at Johannesburg, South Africa, in 2002; and the Conference on Sustainable Development (UNCSD [Rio+20]), held again in Rio de Janeiro, Brazil, in 2012, and the ongoing progressively and advancing processes of these Conferences aimed at achieving SD. The acronym of these UN Conferences may be expressed as 'SRJR', while the course of achieving SD pursuant to the SRJR Conferences and their ongoing outcomes, so far, may be called the 'SRJR Process'. 6

So, in pursuance of the UN SRJR Process, the main recommendation of the WCED, expressed in the Commission's report entitled Our Common Future (the future of the entire global community on Planet Earth), which was published in 1987 , is that the solution to the compelling demand for environmental protection in the course of economic development should be a new approach, namely SD. In other words, the WCED considers SD as the solution to increasing global environmental degradation, devastation and despoliation, which were (and still being) occasioned in the course of economic development. The Commission thus serves Our Common Future as a notice to the entire community of peoples and countries of the globe that time has come for a marriage of economy and ecology, so that governments and their peoples can take responsibility to change their policies, processes and practices that cause these degradation, devastation and despoliation as well as threaten the security and very survival of the human race, other forms of nature and natural resources on Planet Earth. ${ }^{7}$

\footnotetext{
${ }^{1}$ R. Prescott-Allen, The Wellbeing of Nations: A Country-by-Country Index of Quality of Life and the Environment (Island Press 2001); J. Carew-Reid et al, Strategies for National Sustainable Development: A Handbook for their Planning and Implementation (Sustainable Development Set) (IUCN 1994/Earthscan 2009); R. Allen, How to Save the World: Strategy for World Conservation (Corgi Children's 1982). ${ }^{2}$ T. Jackson, Prosperity without Growth?: The Transition to a Sustainable Economy (Sustainable Development Commission 2009); T. Jackson, Prosperity without Growth: Economics for a Finite Planet (Earthscan 2011).

${ }^{3}$ The World Commission on Environment and Development (WCED), Our Common Future (Oxford University Press 1987), x-23.

${ }^{4}$ UK SD Commission, 'History of SD' <http://www.sd-commission.org.uk/pages/history_sd.html> Accessed 7 February, 2020.

${ }^{5}$ Ibid.

${ }^{6}$ E. T. Bristol-Alagbariya, Petroleum Development \& the Environment in Rivers State Nigeria: Fallouts of the UNEP Report on Ogoniland, Environmental Regulatory Standards \& Sustainable Development Laws \& Practices (LAP LAMBERT Academic Publishing 2018), 43; C/f A. C. Kallhauge et al (eds), Global Challenges: Furthering the Multilateral Process for Sustainable Development, (Greenleaf Publishing 2005), 16-30; E. T. Bristol-Alagbariya, 'Environmental Assessment Law towards Sustainable Development in Nigeria and the New Partnership for Africa's Development Action Plan for the Environment Initiative' [2016] Environmental \& Planning Law Review (ELPR), 13 (1-2), 2016, 1294.

${ }^{7}$ WCED (n4), back cover review; P. Bartelmus, Sustaining Prosperity, Nature and Wellbeing; What Do the Indicators Tell Us? (Routledge 2018); D. A. Munro, Caring for the Earth: A Strategy for Sustainable Living (Union Internationale pour la Conservation de la Nature et de
} 
Our Common Future gives a classical definition of SD as the development which meets the needs of the present without compromising the ability of future generations to meet their own needs. ${ }^{1}$ On its part, the Earth Charter Initiative (ECI), which espouses the values and principles for building a more just, sustainable and peaceful world, highlights that SD expands our vision towards ethical or greater ethical principles and practices. ${ }^{2}$ This Charter is an international declaration of fundamental values and principles, having its constituent global movement of organisations and individuals that embrace the declaration for building vision, attitude, knowledge, wisdom, skills and values needed to achieve a more just, sustainable and peaceful global society. ${ }^{3}$

It is at this juncture necessary to state the key and precise outcomes of the above-stated UN Conferences. Having considered the need for a common outlook and for common principles to inspire and guide the peoples and countries of the world to preserve and enhance the human environment, the main outcome of the UNCHE, 1972, is the Stockholm Declaration. A decade after the UNCHE, the assembly of the world community took place in Nairobi, Kenya, 1982, and made a Declaration known as the UN Nairobi Declaration of that year. ${ }^{4}$ Thereafter, the UNCED, 1992, produced certain major outcome documents. These include the Rio Declaration on Environment and Development, often called 'the Rio Declaration', which is a series of principles defining the rights and responsibilities of UN member-states (i.e., sovereign states) on issues of the environment and development. ${ }^{5}$ The Rio Declaration is one of the three major agreements designed to guide future approaches of the global community towards SD and one of the five outcome documents of the UN Rio de Janeiro Earth Summit. Other major agreements of the Rio de Janeiro Earth Summit are the UN Agenda 21 and the Statement of Forest Principles. The rest of the outcome documents and legally binding instruments of the UN Rio de Janeiro Earth Summit are the UN Framework Convention on Climate Change and the Convention on Biological Diversity. ${ }^{6}$ Also, the main outcome document of the WSSD, 2002, is the Johannesburg Declaration on SD. ${ }^{7}$ Finally, the major outcome document of the UNCSD, 2012, is entitled 'Focused Political Outcome Document ... The Future We Want - Outcome Document [Our Common Vision]' ${ }^{8}$

The gradual but progressively advancing efforts of the UN on the environment towards SD, from the UNCHE, 1972, to the UNCSD, 2012, and the forward-looking and dynamic ongoing processes of these Conferences may be considered as constituting a spotlight on the concept and history of SD, as well as the key and precise outcomes of these Conferences and their ongoing processes and vitalising trend towards achieving SD in the overall interest of humanity, the environment and all other forms of nature on Planet Earth.

\section{Features of SD and SD-Oriented Strategies and Initiatives}

Features of SD and SD-Oriented strategies and other initiatives of SD may, among other things, be considered to range from the two key concepts inherent in SD (namely the concept of 'needs', and the idea of 'limitations') through the component aspects, principles and indicators, up to the strategies and other SD-oriented initiatives, which are increasingly being designed to achieve SD.

It may be pertinent to begin with the two key concepts inherent in SD. It would be recalled that the WCED highlights that the definition of SD has two key concepts, namely the concept of 'needs', and the idea of 'limitations'. ${ }^{9}$ The concept of 'needs' particularly refers to the essential and priority 'needs of the world's poor', while the idea of 'limitations' is associated with same, 'imposed by the state of technology and social organisation' with regard to the ability of the environment to meet the needs of present and future generations of humanity. ${ }^{10}$ These concepts bring into play the idea of 'conservation', which is the simple and precise message of the WCS. ${ }^{11}$

Next to be addressed are the aspects (i.e., component aspects, pillars or spheres) of SD, which are basically

\footnotetext{
ses Ressources, Switzerland 1994); IUCN et al, Caring for the Earth: 5 (Sustainable Development Set) (Earthscan 2009).

${ }^{1}$ WCED (n4), 8, 40 and 43.

${ }^{2}$ Homepage of the Earth Charter Initiative $<$ http://earthcharter.org/ $\square$ Accessed 7 February 2020; The Earth Charter, 'Earth Charter Education' $<$ https://earthcharter.org $\square$ Accessed 7 February, 2020.

${ }^{3}$ Ibid; P. B. Corcoran (ed), The Earth Charter in Action: Toward a Sustainable (KIT Publishers 2006); UN Association of Australia (UNAA), The Earth Charter (UNAA 2017).

4 'Report of the United Nations Conference on the Human Environment Stockholm, 5-16, June 1972'<http://www.imo.org/en/KnowledgeCentre/ReferencesAndArchives/HistoryofMARPOL/Documents/A\%20CONF.48\%2014\%20Rev.1. pdf $\square$ Accessed 7 February, 2020.

UN Audiovisual Library of International Law, 'Rio Declaration on Environment and Development' $<$ https://legal.un.org/avl/pdf/ha/dunche/rio ph_e.pdf $\square$ ’ Accessed 7 February, 2020.

${ }^{6}$ UN SD Goals Knowledge Platform', 'United Nations Conference on Environment and Development (UNCED), Earth Summit' $<$ https://sustainabledevelopment.un.org/milestones/unced $\square$ Accessed 7 February, 2020.

7 Europa, 'The Johannesburg Declaration on Development' $<$ https://ec.europa.eu/environment/archives/wssd/documents/wssd_pol_declaration.pdf $\square$ Accessed 7 February, 2020.

${ }^{8}$ UN SD Goals Knowledge Platform', 'Future We Want - Outcome Document' $<$ https://sustainabledevelopment.un.org/futurewewant.html Accessed 7 February, 2020; UNGA, 'Resolution adopted by the General Assembly on 27 July 2912 66/288. The Future We Want [dated 11 September 2012]' <https://www.un.org/ga/search/view_doc.asp?symbol=A/RES/66/288\&Lang=E $\square$ Accessed 7 February, 2020.

${ }^{9}$ WCED (n4), 43.

${ }^{10}$ Ibid.

${ }^{11} \mathrm{IUCN}$ et al (1980 [n1]).
} 
its economic, social, environment and governance spheres of SD, as well as its ecological and cultural components. Among these, the governance aspect of SD, namely good public sector governance (good political leadership [GG]), is very significant, key and most compelling. GG and SD are, in fact, indivisible, as SD cannot be achieved without GG, as it is SD's foremost, greatest and most significant enabler. ${ }^{1}$ On this note, while highlighting the key significance of GG to SD, the Seventh UN Secretary-General (1 January, 1997 - 31 December, 2006), Kofi Annan, proclaims, on July 28, 1997, at the UN 'International Conference on Governance for Sustainable Growth and Equity', New York, 28-30 July, 1997, that 'good governance and sustainable development are indivisible'.2

The foregoing proclamation of Kofi Annan explains, underscores and echoes the relationship and key significance of GG to development, prosperity, peace and SD in society. In fact, considering the preconditions, particularly the mandatory requirements, towards more just, sustainable and peaceful global society, the role of GG in member-states of the UN cannot be overstressed. Certainly, the concept of SD may be intellectually interpreted differently; nevertheless, it is crystal clear that SD holds governments accountable to ensure that the needs of society, the economy and the environment were properly balanced in government decision-making and decision-implementation processes as well as in the overall course and/or processes of governance. Moreover, as conceived and practised by UN member-states, SD and its oriented courses, measures and processes etcetera constitute a platform and provide an approach for making and implementing better decisions on basic issues affecting society, particularly the needs of society, such as those of the economy, political economy at large, and the wellbeing of the environment, humanity and overall nature on Planet Earth. ${ }^{3}$ No doubt therefore, there is an evident, urgent and inevitable need for $\mathrm{GG}$, to pilot the affairs of sovereign states towards $\mathrm{SD},{ }^{4}$ and this is particularly so regarding developing countries and least developed countries (i.e., less economically developed countries [LEDC]). ${ }^{5}$

With respect to principles, SD has the following principles, namely the precautionary principle, pollution prevention pays principle $(3 p+)$, polluter pays principle (PoPP), user pays principle (UPP), principle of intragenerational equity, principle of inter-generational equity, and the principle of public participation. One, the Precautionary Principle, which is expressed in Principle 15 of the Rio Declaration on Environment and Development, 1992, (as well as evident in Principle 17 of this Declaration on EIA), stipulates that where there are threats of significant, serious or irreversible damage, the lack of full scientific knowledge shall not be used as a reason for postponing cause effective means to prevent environmental degradation, despoliation and devastation. Two, the Pollution Prevention Pays Principle $(3 \mathrm{P}+)$ encourages industry to invest positively to prevent environmental pollution. Three, the Polluter Pays Principle (PPP, stated in Principle 16 Rio Declaration on Environment and Development, 1992), provides that the polluter should pay the costs of preventing, controlling and remedying pollution. Four, the User Pays Principle (UPP) stipulates that the cost of a resource to a user must include all the environmental costs associated with its extraction, transformation and usage, including the cost of foregone alternative or future uses or usages. Five, the Principle of Intra-Generational Equity postulates that different groups of people within a country or among its present generation of humans have the right to benefit equally, fairly, equitably and in a socially justifiable manner from the exploitation of resources, and that they have equal right to a healthy (a clean, safe and ecologically sound [non-harmful) environment. This is because a healthy environment is a precursor to a healthy people and a healthy society. Six, the Principle of Inter-Generational Equity requires that the needs of present generation are met without compromising the ability of future generations to meet their own needs. Seven and lastly, the Principle of Public Participation, often simply described as

${ }^{1}$ WCED (n4), x-23, particularly 9; K. Annan, 'International Conference on Governance for Sustainable Growth and Equity', New York, 2830 July, 1997 <http://www.pogar.org/publications/other/undp/governance/annan-address-e.pdf > Accessed 28 January, 2019 ; G. Ayre and R. Callway (eds), Governance for Sustainable Development: A Foundation for the Future (Earthscan 2005); H. Clark, The Importance of Governance for Sustainable Development (The Institute of Southeast Asian Studies [ISEAS] Publishing 2012).

${ }^{2}$ UN, 'Meetings Coverage and Press Releases: Good Governance Essential to Development, Prosperity, Peace Secretary-General Tells International Conference, Press Release SG/SM/6291/DEV/2166'<https:/www.un.org/press/en/1997/19970728.SGSM6291.html $\square$ Accessed 7 February, 2020

${ }^{3}$ UK SD Commission, 'What is Sustainable Development' http://www.sd-commission.org.uk/pages/what-is-sustainable-development.html Accessed 7 February, 2020

${ }^{4}$ WCED (n4), x-23, particularly 9; E. T. Bristol-Alagbariya, Governance Towards Sustainable Development in Nigeria: The Role of Strategic Assessment of Decisions \& Actions (Centre for Energy, Petroleum \& Mineral Law \& Policy [CEPMLP]/Dundee University Press [DUP] 2013), xxxvii-xxxviii, 46-49 and 272-393; E. T. Bristol-Alagbariya, Participation in Petroleum Development: Towards Sustainable Community Development in the Niger Delta (CEPMLP/DUP 2010), 75-82 and 329-337; K. Ginther et al (eds), Sustainable Development and Good Governance (Martinus Nijhoff Publishers 1995); G. Ayre and R. Callway (eds) (n20); H. Clark (n20); T. Edoh and T. Wuam (eds), Democracy, Leadership And Accountability in Post-Colonial Africa: Challenges And Possibilities: Essays in Honour of Professor Akase Paul Sorkaa (Aboki Publishers 2009); T Wuam and T. N. Sunday (eds), Governance and Economic Development in the Fourth Republic (Aboki Publishers 2010).

${ }^{5}$ International Investing, 'What Is a Developing Country?'< <https://www.thebalance.com/what-is-a-developing-country-1978982 $\square$ Accessed 7 February, 2020; 'Country UN Classification: United the Nations' $<$ https://www.un.org/en/development/desa/policy/wesp/wesp_current/2014wesp_country_classification.pdf $\square$ Accessed 7 February, 2020; European Union, 'Developing Countries and Emerging Markets' <https://ec.europa.eu/knowledge4policy/foresight/topic/growingconsumerism/developing-countries-emerging-markets_en $\square$ Accessed 7 February, 2020. 
'participation' (which environmental democracy is an aspect), requires that decisions should, as much as possible, be made by the members of the public, who are affected, or on their behalf by the authorities closest to them. ${ }^{1}$ Participation involves interactively taking part in decision-making. It broadly means to inform, consult, involve, collaborate with and empower affected members of the public (citizens and citizen-groups alike) in the process of decision-making. Participation is a way of informing, consulting, involving, collaborating with and empowering affected members of the public in decision-making and decision-implementation processes, so as to place final decisions in their hands, by implementing what they decide. ${ }^{2}$ These principles of SD convey the links between development processes, environmental factors, and human and other resources of nature. ${ }^{3}$

SD also has its indicators, which are known as SD Indicators (SDIs). An indicator may be described as a device that shows what a situation is like, such as a value, or a change in level, speed, etcetera, and thus demonstrates the existence of the given situation or clarifies that the situation is true or otherwise. ${ }^{4}$ It is a measurement tool, such as a gauge or meter, guide or standard, sign or signal, which indicates the state, level or degree of something. By virtue of certain indices, indicators measure trends towards SD, so as to enable UN member-states, organisations (including private sector organisations) and peoples around the world, to measure, monitor, evaluate and effectively streamline their efforts towards SD. ${ }^{5}$ SDIs are directly or indirectly associated with human wellbeing, as they are all targeted towards achieving the wellbeing of humans, the environment and overall nature on Planet Earth. ${ }^{6}$

The UN Agenda 21 is also of core significance and thus indispensable in the realm of ongoing global efforts towards SD. Agenda 21 has already been described in this study as one of the outcome documents of UN Conference on Environment and Development, 1992, which is designed to guide the intertwined and interwoven relationship of the environment to development, and thus future approaches to development towards SD. The UN Agenda 21 is a global plan of action to promote SD. It is an extensive blueprint and very exhaustive plan outlining necessary actions towards the achievement of SD worldwide, ranging from local to national and then international levels. ${ }^{7}$ Agenda 21 may also be construed as a 'greenprint' for global partnership, which aims at a high quality environment and a healthy economy for all peoples around the globe. It focuses on critical issues confronting the entire global community, such as continuing damage to ecosystems; worsening poverty, hunger and ill health; increasing world population and illiteracy. It is made up of 40 Chapters, which identify each challenge and proposes simple and realistic solutions towards SD. From the UN Agenda 21, member-states of the UN were to design and develop, and did, in fact, design and develop their respective Agenda 21, as their distinct and separate instruments towards $\mathrm{SD}$, in their respective jurisdictions. ${ }^{8}$

Using economic mechanisms as one of the means of achieving SD, there is the Green Economy Initiative. ${ }^{9}$ This Initiative is designed in the UN system as a contemporary dominant economic model, which has the potential to enhance SD and poverty reduction, towards accelerating human wellbeing, environmental protection and preservation of ecology and ecosystems. ${ }^{10}$

${ }^{1}$ FEPA, National Policy on the Environment (FEPA 1999) 1; Principle 1, Rio Declaration on Environment and Development, 1992.

The International Association of Public Participation (IAP2), 'IAP2 Spectrum of Public Participation' $<$ https://cdn.ymaws.com/www.iap2.org/resource/resmgr/pillars/Spectrum_8.5x11_Print.pdf $\square$ Accessed 7 February, 2020.

${ }^{3}$ FEPA, National Policy on the Environment (n25) 1; Principle 1, Rio Declaration on Environment and Development, 1992.

${ }^{4}$ Cambridge Dictionary, 'Indictor' $<$ https://dictionary.cambridge.org/dictionary/english/indicator $\square$ Accessed 7 February, 2020.

${ }^{5}$ The UN Department on Economic and Social Affairs (UNDESA), Indicators of Sustainable Development: Guidelines and Methodologies (UN 2007); UN Sustainable Development Knowledge Platform, 'Indicators in the Transforming Our World - The 2030 Agenda for Sustainable Development' $\quad<$ https://sustainabledevelopment.un.org/topics/indicators $\square$ Accessed 7 February, 2020; P. Gennari, 'Key Indicators of Sustainable Development' <https://www.mofa.go.jp/policy/economy/eismap/k seminar/Round-2-3.pdf $\square$ Accessed 28 January, 2019; The Department of Environment, Food and Rural Affairs (DEFRA) UK, Sustainable Development Indicators July 2013 (The National Archives/Sustainable Development Statistics 2013); S. Bell and S. Morse, Sustainability Indicators: Measuring the Immeasurable? (Earthscan 2008).

${ }^{6}$ FEPA, National Policy on the Environment (n25) 1; Principle 1, Rio Declaration on Environment and Development, 1992; Cambridge Dictionary, 'Indictor' Nature Geoscience, 'Sustainability on Earth'<https://www.nature.com/collections/mzyhgncgsm $\square$ Accessed 7 February, 2020.

7 UN SDGs Knowledge Platform, Division of SDGs, Department of Economic and Social Affairs (DESA), 'Agenda 21' $<\mathrm{https}$ ://sustainabledevelopment.un.org/outcomedocuments/agenda21

$<$ https://sustainabledevelopment.un.org/content/documents/Agenda21.pdf $\square$ both Accessed 7 February, 2020.

${ }^{8}$ UN SDGs Knowledge Platform, Division of SDGs, DESA, 'United Nations Conference on Environment and Development Rio de Janeiro Brazil, 3 to 14 June 1992 Agenda 21'<https://sustainabledevelopment.un.org/content/documents/Agenda21.pdf $\square$ Accessed 7 February, 2020; FEPA, Nigeria's National Agenda 21 (FEPA 1999).

${ }^{9}$ Paragraph 102, 'Focused Political Outcome Document of the UNCSD (Rio+20), 2012, 'The Future We Want - Outcome Document', captioned 'Green Bridge Partnership Programme' towards SD.

${ }^{10}$ W. L. Filho et al (eds), Sustainable Economic Development: Green Economy and Green Growth (Springer International Publishing 2017); J, A. Puppim de Oliveira (ed), Green Economy and Good Governance for Sustainable Development: Opportunities, Promises and Concerns (UN University Press 2012); W. Hynes and S. Wang, Green Growth and Developing Countries: A Summary for Policy Makers (The Organisation for Economic Co-operation and Development [OECD] 2012); UN System Chief Executives Board for Coordination, 'Green Economy Initiative'< https://www.unsystem.org/content/green-economy-initiative-gei $\square$ Accessed 7 February, 2020; UNEP, 'Green Industrial Policy: Concept, Policies, Country Experiences' $<$ https://www.unenvironment.org/resources/report/green-industrial-policy-concept-policiescountry-experiences $\square$ Accessed 7 February, 2020. 
Concerning SD Goals, there has been a transition from the Millennium Development Goals (MDGs) to the SD Goals (SDGs) in the UN system. Efforts of the entire global community to achieve SD commenced from the historic inspirational targets (known as the UNMDGs), to the extant, monumental and aspirational targets (known as the UNSDGs). In the process, by its Resolution 53/202 of 17 December, 1998, the UN General Assembly (UNGA), decided to designate its $55^{\text {th }}$ Session, 'The Millennium Assembly of the UN', and to convene, as an integral part of the Millennium Assembly, a Millennium Summit of the UN (UNMS), ${ }^{1}$ which took place between Wednesday, 6 September, and Friday, 8 September, 2000, at UN Headquarters, in New York. The principal document that was unanimously adopted by the UNMS was the UN Millennium Declaration, which expresses a statement of values, principles and objectives comprising an international agenda for the $21^{\text {st }}$ Century. To commit countries and people of the world, the Summit framed a series of Eight time-bound Goals, known as the MDGs, which are to be achieved by the target year, 2015. As nations and peoples of the world, particularly those of developing countries, were unable to achieve the MDGs by the target year (2015), the worldwide community, under the auspices of the UN, introduced the SD Goals (SDGs), which are Seventeen in number. These Seventeen UNSDGs are designed to end poverty, protect the planet, and ensure peace and prosperity for all as part of a new SD agenda. ${ }^{3}$ The SDGs, also known as 'Global Goals', constitute a blueprint to achieve a better and more sustainable future for all. ${ }^{4}$ The Goals address global challenges confronting humanity, countries and society at large, such as poverty, inequality, climate change, environmental degradation, peace and justice. These Seventeen Goals are interconnected, and are meant to be achieved by the target year (2030), so as not to leave any country or people behind (without achieving them by the afore-stated target year). ${ }^{5}$ Each of the Seventeen SDGs has specific targets to be achieved over a fifteen year period (from 2015), and all sectors of society, namely government, the private sector, civil society and individuals, ought to fulfil their roles for these Goals to be achieved. ${ }^{6}$

\section{Efforts towards SD: The Wellbeing of Humans and Overall Nature on Planet Earth}

Global efforts as well as those of respective peoples and sovereign states around the world, aimed at achieving $\mathrm{SD}$, are basically centred on the wellbeing of humans and overall nature on Planet Earth. ${ }^{7}$ To this end, the concept of SD may be considered as being humane, as it emphasises the need for human wellbeing, from the background and perspective of the universally recognised and accepted dignity of all human beings, which are stipulated in the Universal Declaration of Human Rights, $1948 .{ }^{8}$ SD advocates and enhances human wellbeing in the context of harmonious relationship between humans and nature at large. ${ }^{9}$ It therefore emphasises the wellbeing of humanity, the environment, ecology, ecosystems, and overall nature on Planet Earth. It is on this note that SD requires a healthy environment, which is clean, safe and ecologically-sound. This means an environment that is not harmful but beneficial to humans and overall nature. For this reason, SD emphasises and pursues how to achieve human wellbeing and harmonious relationship between humans and other varieties of nature on Planet Earth. ${ }^{10}$

The term 'wellbeing' is a very broad, elastic, versatile and an all-embracing one. ${ }^{11}$ Wellbeing in Developing Countries (WeD) Research Group, Centre for Development Studies, Bath University, Somerset, England, United Kingdom, defines wellbeing in the following manner:

\footnotetext{
UN, 'Conferences, Meetings and Events: Millennium Summit $\left(\begin{array}{lllllll}6 & - & 8 & \text { September } & 2000)\end{array}\right.$ $<$ https://www.un.org/en/events/pastevents/millennium summit.shtml $\square$ Accessed 7 February, 2020.

${ }^{2}$ UN, 'Millennium Development Goals and Beyond 2015: News on Millennium Development Goals' $<$ https://www.un.org/millenniumgoals/ $\square$ Accessed 7 February, 2020.

${ }^{3}$ UNGA, 'Resolution adopted by the General Assembly on 25 September 2015 70/1: Transforming our world: the 2030 Agenda for Sustainable Development' <https://www.un.org/ga/search/view_doc.asp?symbol=A/RES/70/1\&Lang=E $\square$ Accessed 7 February, 2020; UN, 'A/RES/70/1 - Transforming our world: the 2030 Agenda for Sustainable Development 21 Oct 2015, $<$ https://sustainabledevelopment.un.org/index.php?page=view\&type=111\&nr=8496\&menu=35 $\square$ Accessed 7 February, 2020; UNDP, UN SDGs $<$ https://www.undp.org/content/undp/en/home/sustainable-development-goals.html $\square$ Accessed 7 February, 2020.

${ }^{4}$ UNDP, UN SDGs (n37).

${ }^{5}$ UN, 'Sustainable Development Goals: About the Sustainable Development Goals' $<$ https://www.un.org/sustainabledevelopment/sustainabledevelopment-goals/ $\square$ Accessed 7 February, 2020.

${ }^{6}$ Ibid.

${ }^{7}$ P. Dasgupta, Human Well-Being and the Natural Environment (Oxford University Press 2004); R. J. Estes and M. J. Sirgy (eds) The Pursuit of Human Well-Being: The Untold Global History (International Handbooks of Quality-of-Life) (Springer International Publishing 2017); M. Mc Gillivray and M. Clarke, Understanding Human Well-Being (Bookwell Publications 2007); Millennium Ecosystem Assessment, Ecosystems and Human Well-Being: Synthesis Report (Millennium Ecosystem Assessment Series) (Island Press 2005); Millennium Ecosystem Assessment, Ecosystems and Human Well-Being: A Framework for Assessment (Millennium Ecosystem Assessment Series) (Island Press 2003). ${ }^{8} \mathrm{UN}$, 'The Universal Declaration of Human Rights' 1948, < https://www.un.org/en/universal-declaration-human-rights/ $\square$ Accessed 7 February, 2020; A. Austin, A Universal Declaration of Human Well-Being (Wellbeing in Politics and Policy) (Palgrave Macmillan 2020).

${ }^{9}$ Principle 1, Rio Declaration on Environment and Development, 1992, which provides that human beings are at the centre of concerns for sustainable development. They are entitled to a healthy and productive life in harmony with nature; UNEP, Healthy Environment, Healthy People (UNEP 2016); Goal 3, UN SDGs, captioned 'Good Health and Wellbeing'; J. F. Sachs, The Age of Sustainable Development (University of Columbia Press 2015).

${ }^{10}$ Ibid; D. C. Esty (ed), A Better Planet: 40 Big Ideas for a Sustainable Future (Yale University Press 2019); G. R. Lueddeke, Survival: One Health, One Planet, One Future (Routledge Studies in Sustainability) (Routledge 2019); D. A. Munro (n8); IUCN et al (2009 [n8]).

${ }^{11}$ Department for Environment, Food and Rural Affairs (DEFRA), UK, Sustainable Development Indicators in Your Pocket 2009: An Update of the UK Government Strategy Indicators, (DEFRA 2009), 119.
} 
a state of being with others, where human needs are met, where one can act meaningfully to pursue one's goals, and where one enjoys a satisfactory quality of life. ${ }^{1}$

The UK Government defines wellbeing in the following manner:

a positive physical, social and mental state; it is not just the absence of pain, discomfort and incapacity. It requires that basic needs are met, that individuals have a sense of purpose, that they feel able to achieve important personal goals and participate in society. It is enhanced by conditions that include supportive personal relationships, strong and inclusive communities, good health, financial and personal security, rewarding employment, and a healthy and attractive environment. Consequently, numerous factors may influence an individual's wellbeing. ${ }^{2}$

Various definitions, analyses and discussions on wellbeing basically capture a state of equilibrium or balance that can be affected by life events or challenges in relation to humans and other resources of nature on Planet Earth. ${ }^{3}$ Consequently, the concept, principle, rule, theory, regulatory practice and increasingly emerging worldwide law of SD emphasises the need for equitable caring for societies around the world and the entire global community, which recognises the essence of human wellbeing and harmonious relationship between humanity and overall nature on our Planet (Mother) Earth. ${ }^{4}$

\section{Sustainable Development as a Soft Law Concept Transforming SD-Oriented Strategies into Hard Law Instruments in UN Member-states}

The foregoing sub-heading has already explained SD as a concept and principle concerned about and thus in pursuit of the wellbeing of humanity, the environment, ecosystems and overall nature around the globe. SD is certainly a soft law and increasingly emerging hard law concept, principle and regulatory practice of overall wellbeing of nature on Planet Earth. ${ }^{5}$

Briefly put, the term 'soft law', which is passionately being debated on by scholars of the legal profession and law-related multidisciplinary scholars worldwide, denote a wide variety of global and other international legal and regulatory instruments, such as treaties, declarations, resolutions, principles and other related instruments, which have persuasive effects in the domestic jurisdictions of sovereign states, rather than being out rightly (legally) binding in domestic spheres of sovereign states, except and/or until when any of such instruments is specifically incorporated and adopted into the legal system of these states. ${ }^{6}$ Examples of soft law are UN General Assembly [UNGA] declarations, recommendations and resolutions, bilateral and multilateral treaties, as well as voluntary resolutions, recommendations, codes of conduct, guidelines, norms and standards, which emanate from the international sphere. ${ }^{7}$ Thus, although soft law mechanisms are modes of conduct may govern or regulate the humans, business (the private sector), government and overall society in the domestic jurisdiction of a sovereign state, they (soft law mechanism) are distinct from those of hard laws. Soft law mechanisms may be distinguished from hard laws (especially positive law [legal positivist] instruments), which are obligatory modes of conduct that are outrightly binding on the parties to them and can thus be promptly and legally enforced against any of the parties. Often hard laws govern humans and society at large, within domestic jurisdictions of sovereign states, ${ }^{8}$ as distinct from soft laws, which emanate from and mainly exist within the entire global arena and other international spheres. Due to ongoing advancing efforts of the UN on the environment and development so as to achieve SD and similar other international efforts, such as those of the global extractive industrial operations (EIOs) sector,

\footnotetext{
${ }^{1}$ Economic and Social Research Council (ESRC) Research Group on Wellbeing in Developing Countries, 'Research Statement' $<$ http://www.bath.ac.uk/soc-pol/welldev/research/aims.htm $\square$ Accessed 7 February, 2020; Economic and Social Research Council (ESRC) Research Group on Wellbeing in Developing Countries, 'Working Papers'<http:/www.bath.ac.uk/soc-pol/welldev/research/working.htm $\square$ Accessed 7 February, 2020

${ }^{2}$ Department for Environment, Food and Rural Affairs (DEFRA), UK (n45), 119-120; DEFRA UK, 'Sustainable Development Indicators in Your Pocket' <https://data.gov.uk/dataset/cbd3ee8e-5bfb-4c2a-85b0-7a5b2ae4ffa1/sustainable-development-indicators-in-your-pocket $\square$ Accessed 7 February, 2020.

${ }^{3}$ R. Dodge et al, 'The Challenge of Defining Wellbeing' [2012] 2 (3) International Journal of Wellbeing, $222-235$.

${ }^{4}$ E. T. Bristol-Alagbariya (2018 [n7]); M. C. Segger and A. Khalfan, Sustainable Development Law: Principles, Practices, \& Prospects (Oxford University Press 2005); A. Ross, Sustainable Development Law in the UK: From Rhetoric to Reality? (Earthscan 2012); M. Decleris, The Law of Sustainable Development: General Principles: A Report of the European Commission (European Commission 2000); J. J. Kirton and M. J. Trebilcock (eds), Hard Choices, Soft Law: Voluntary Standards in Global Trade, Environment and Social Governance (Global Environmental Governance Series) (Routledge 2016).

${ }^{5}$ E. T. Bristol-Alagbariya (2018 [n7]); M. C. Segger and A. Khalfan (n49); A. Ross, Sustainable Development Law in the UK: From Rhetoric to Reality? (Earthscan 2012); M. Decleris (n49); J. J. Kirton and M. J. Trebilcock (eds) (n49).

${ }^{6}$ Section 12, 1999 Constitution of the Federal Republic of Nigeria (CFRN) (as amended), captioned 'Implementation of Treaties'.

${ }^{7}$ L. Haocai and S. Gongde, Soft Law Governance: Towards an Integrated Approach (William S. Hein \& Co 2013); K. W. Abbott and D. Snidal, 'Hard and Soft Law in International Governance' [2000] 54 (3) International Organization, 421-456; R. R. Baxter, 'International Law in 'Her Infinite Variety' [1980] 29 (4) International and Comparative Law Quarterly, 549-566.

${ }^{8}$ P. Westerrman et al (eds), Legal Validity of Soft Law (Springer International Publishing 2018); A. T. Guzman and T. L. Meyer, 'International Soft Law' [2010] 2 (1) The Journal of Legal Analysis, 171-225; J. B. Skjærseth et al, 'Soft Law, Hard Law, and Effective Implementation of International Environmental Norms' [2006] 6 (3) Global Environmental Politics, 104-120; U. Etemire, 'Reflections on the Role of International Custom and Soft Law in Environmental Protection' [2016] 1 (1) UNIPORT Journal of Public Law, 60-61; European Center for Constitutional and Human Rights (ECCHR), 'Term Hard law/Soft Law'<https://www.ecchr.eu/en/glossary/hard-law-soft-law/> Accessed 7 February, 2020.
} 
particularly the global petroleum industrial sector, ${ }^{1}$ benchmarked soft law regulatory mechanisms are evolving to govern issues of the environment and development that are impacting negatively on SD, such as issues of major natural resources EIOs around the globe, especially such development operations taking in resources-rich developing countries that are plagued by the resource curse. ${ }^{2}$

In the ongoing era of SD, benchmarked global and widely recognised and accepted international soft law regulatory mechanisms, such as guidelines, peer-reviews, policies, principles, norms, road maps, rules, standards and practices, on the environment and development, especially those of EIOs, such as oil and gas and other mining and mineral and major natural resources industrial development operations, are impacting on the initiatives and actions of sovereign states towards SD. ${ }^{3}$ These benchmarked global and international soft law regulatory mechanisms are transforming domestic frameworks of global sovereign states towards good public governance (GG), particularly good human rights governance and good environmental rights governance, premised on careful, sound and prudent protection, development and management of the environment, ecological conservation, and the wellbeing of humans and other resources of nature on Planet (Mother) Earth. ${ }^{4}$ These soft law mechanisms are increasingly having the compelling force and effects of hard laws in developing countries, particularly resourcesrich developing countries, and are thereby transforming developmental PPPs associated with the environment, towards (GEG) and thus promoting GG and SD, towards a fairer, more just, sustainable and peaceful world. ${ }^{5}$ It is therefore crystal clear that SD is a peculiar soft law concept, principle, rule, theory and regulatory practice, which is transforming SD-oriented strategies and other forms of SD-related initiatives into hard law instruments in sovereign states, so as to promote the wellbeing of humans, the environment and overall nature on Earth. ${ }^{6}$

\section{Efforts towards SD and Development Partnerships around the Globe}

Efforts towards SD in sovereign states, which are member-states of the $\mathrm{UN}$, are increasingly giving rise to a variety of collaborations and partnerships within these states and internationally, such as in the form of bilateral and regional cooperative arrangements and beyond. These include various forms of SD-oriented partnerships between and among major UN groups and other stakeholders, such as between and among those of Global South-South and Global North-South. ${ }^{7}$ Consequently, some measures of cooperation and partnership towards SD are taking place in the form of Public Private Sector Partnerships (PPSPs) and partnerships among government institutions and agencies of sovereign states around the globe. These measures of partnerships may be in the form of generic or relatively generic economic development agreements (EDAs) and those concerning specific developmental plans, policies and programmes (including projects [PPP] in developing countries. Developmental partnerships are also taking place between and among institutions and agencies of governments of advanced countries and those of

\footnotetext{
${ }^{1}$ International Institute for Environment and Development (IIED) and World Business Council for Sustainable Development (WBCSD), Breaking New Ground: Mining, Minerals, and Sustainable Development: The Report of the MMSD Project (Earthscan 2002); World Bank Group, 'Striking a Better Balance - The World Bank Group and Extractive Industries: The Final Report of the Extractive Industries Review, World Bank Group Management Response' <http://documents.worldbank.org/curated/en/961241468781797388/pdf/300010GLB.pdf Accessed 5 October, 2019; homepage of the Global Mining Guidelines Group <https://gmggroup.org/ $\square$ Accessed 5 October, 2019; homepage of the Global Mining Institute $<$ https:/home.kpmg/xx/en/home/industries/mining.html $\square$ Accessed 5 October, 2019; International Quality and Productivity Center (IQPC), 'Introduction to Oil and Gas Industry: Learn about the three key sectors in oil and gas, the current state of the industry and future outlook' $<$ https://www.oilandgasiq.com/strategy-management-and-information/articles/oil-gas-industry-an-introduction $\square$ Accessed 5 October, 2019.

${ }^{2}$ Principle 3, UN Stockholm Declaration on the Human Environment, 1972; E. T. Bristol-Alagbariya (2018 [n7]), 43; E. T. Bristol-Alagbariya (2010 [n23]), 49, 75, 147 and 318; homepage of Nigeria Extractive Industries Transparency Initiative (NEITI) <https://eiti.org/nigeria Accessed 7 February, 2020; homepage of the Earth Charter Initiative (n10); J. Rexler, 'Beyond the Oil Curse: Shell, State Power, and Environmental Regulation in the Niger Delta' [2010] 12 (1) Stanford Journal of International Relations, 26 -31.

${ }^{3}$ Organisation for Economic Co-operation and Development (OECD), 'Soft Law: Definition' <https://www.oecd.org/gov/regulatorypolicy/irc10.htm $>$ Accessed 7 February, 2020; J. F. Sachs (n43).

${ }^{4}$ D. Shelton, Commitment and Compliance: The Role of Non-binding Norms in the International Legal System (Oxford University Press 2003); S. Lagoutte et al (eds), Tracing the Roles of Soft Law in Human Rights (Oxford University Press 2016); G. Weeks, Soft Law and Public Authorities: Remedies and Reform (Hart Publishing 2016); E. T. Bristol-Alagbariya (2010 [n23]) 327-328; UN Environment Programme (UNEP) (2016 [43]); UNEP, Environmental Assessment of Ogoniland (UNEP 2011); E. T. Bristol-Alagbariya (2018 [n7]) 1, 6, 43, 66 and 74; E. T. Bristol-Alagbariya (2013 [n23]); D. C. Esty (ed) (n44); G. R. Lueddeke (n44); P. Bartelmus (n8).

${ }^{5}$ Homepage of the Earth Charter Initiative (n10); D. A. Munro (n8); IUCN et al (2009 [n8]).

${ }^{6}$ D. C. Esty (ed) (n44); G. R. Lueddeke (n44); P. Bartelmus (n8); D. A. Munro (n8); IUCN et al (2009 [n8]); J. Friedrich, International Environmental "Soft Law": The Functions and Limits of Nonbinding Instruments in International Environmental Governance and Law (Springer Heidelberg 2013); D. Shelton (57); E. T. Bristol-Alagbariya (2018 [n7]) 1, 6, 43, 66 and 74.

${ }^{7}$ Paragraphs 1, 6 and 10, Nairobi Declaration, 1982, on international cooperation to strengthen the protection, management and improvement of the environment; Principle 24, Stockholm Declaration, 1972, on international cooperation towards the protection and improvement of the environment; Principle 27, Rio Declaration, 1992, on cooperation and partnership of UN member-states (i.e., sovereign states of the world) and peoples towards the development of international law in the field of SD; Paragraph 23, Johannesburg Declaration on SD, 2002, on support for stronger regional groupings and improved international cooperation to promote SD; Paragraph 26, Johannesburg Declaration on SD, 2002, on continuity of stable partnerships between and among all major groups towards SD, given the long-term perspective of SD; Paragraphs 55, $64,71,76$ (h), 102, 137, 154, 195, 196, 202, 205, 215, 217, 232, 253, 260, and 280 of the 'Focused Political Outcome Document of the UNCSD (Rio+20), 2012, 'The Future We Want - Outcome Document', on reinvigoration of international cooperation and various forms of partnerships, including global partnerships (of major groups and other stakeholders) towards SD; Chapter 2, UN Agenda 21, captioned 'International Cooperation to Accelerate Sustainable Development in Developing Countries and Related Domestic Policies'.
} 
developing countries and least developing countries, in the form of development aids or other forms of development assistance directed from advanced countries (including economies in transition) to developing countries and least developing countries. ${ }^{1}$ Besides, in domestic jurisdictions of sovereign states, such SD-oriented measures on partnership arrangements are, for instance, taking place between and among such entities as local communities (such as major natural resources-rich local communities), the private sector (business, such as multinational companies [MNCs]) and host governments, such as oil-rich communities, MNOCs and relevant government institutions and agencies. ${ }^{2}$ The UN SRJR Process and its dynamically progressive and continuing outcomes are thus certainly promoting partnerships (beyond domestic jurisdictions of sovereign states) towards $\mathrm{SD}^{3}$

There are examples of SD-oriented partnership mechanisms associated with business sustainability, environmental protection, good environmental governance (GEG), GG and SD, which may be considered in the realm of various forms of collaborations and partnership arrangements being consummated in the course of business towards business sustainability and SD in general. These include the UN Global Compact, the International Finance Corporation (IFC) Sustainability Framework, and the Equator Principles (EPs) for EPs compliant banks like the IFC and the Multilateral Investment Guarantee Agency (MIGA), which govern clients of these EPs complaints banks around the world, particularly in developing countries, where development projects associated with PPSPs, are being financed from international financial sources, are taking place.

UN Global Compact, which may be considered as a fall-out of ongoing economic globalisation, premised on the UN system, is another business sustainability and generic SD mechanism initiated and being superintended by the UN system through the office of the UN Secretary-General. This Compact is the world's largest corporate voluntary sustainability initiative launched by the UN Secretary-General, in July 2000, as a platform for private sector around the globe to support the UN's effort towards SD, in ways that are designed to enhance business sustainability and to benefit humanity, communities and markets around the world. ${ }^{4}$

The EPs are also examples of private sector mechanisms for business sustainability and SD. These principles constitute a risk management framework, adopted by financial institutions, for determining, assessing and managing environmental and social risks associated with development projects. The framework is essentially intended to provide a minimum standard for due diligence to support responsible risk decision-making in the course of development projects financed by the EPs complaint banks (also known as EPs financial institutions (EPFIs). ${ }^{5}$ EPFIs, which belong to an unincorporated association known as the EPs Association (EPsA), formed in July 2010, apply EPs to new projects (globally and across all industry sectors) financed by four financial products, namely project finance advisory services, project finance, project-related corporate loans and bridge loans. ${ }^{6}$ Consequently, for countries to be part of the EPs, there are EPs designated countries. ${ }^{7}$ These are countries that are considered to have robust environmental and social governance, legislation systems and institutional capacity, which are designed to protect the people of such countries and the natural environment thereof. The Equator Principles Association (EPsA) makes no independent assessment of each country's performance in the foregoing areas, so as to make or enable a country qualify to become an EPs designated country. However, as an alternative

\footnotetext{
${ }^{1}$ UN, Paragraph 280 (c), 'Focused Political Outcome Document of the UNCSD (Rio+20), 2012, 'The Future We Want - Outcome Document', captioned 'Supporting North-South, South-South and triangular cooperation for the transition to a resource-efficient economy'; UN SD Goals Knowledge Platform', 'Future We Want - Outcome Document' <https://sustainabledevelopment.un.org/futurewewant.html $\square$ Accessed 7 February, 2020; UNGA, 'Resolution adopted by the General Assembly on 27 July 2912 66/288. The Future We Want [dated 11 September 2012]' <https://www.un.org/ga/search/view doc.asp?symbol=A/RES/66/288\&Lang=E $\square$ Accessed 7 February, 2020; J. Sorens, 'Development and the Political Economy of Foreign Aid' $<$ https://www.independent.org/students/essay/essay.asp?id=2043 $\square$ Accessed 7 February, 2020; OECD, 'OECD Data: Net Official Development Assistance'<https://data.oecd.org/oda/net-oda.htm $\square$ Accessed 7 February, 2020; V. Williams, 'Foreign Aid' <https://www.britannica.com/topic/foreign-aid $\square$ Accessed 7 February, 2020; D. H. Oyola, 'Does foreign aid help the developing countries towards development?'

$<$ https://www.researchgate.net/post/Does_foreign aid help the developing countries towards development $\square$ Accessed 7 February, 2020 ; N. S. Okogbule, Legal Status of Economic Development Agreements (Davis Printing \& Packaging Co. 2004).

${ }^{2}$ Memorandum of Understanding (MoU) Between Bonny Kingdom (Represented by the Amanyanabo of Bonny Kingdom, King Edward Asimini William Dappa Pepple III, JP, CON, Perekule XI) AND The Joint Industry Companies (Comprising Nigeria LNG Limited [NLNG] and The Shell Petroleum Development Company of Nigeria Limited [SPDC] for Sustainable Development of Bonny Kingdom, witnessed by the Rivers State Government (via Her Excellency, the Deputy Governor of Rivers State, Dr (Mrs) Ipalibo Banigo) and the Bonny Local Government (via The Executive Chairman of Bonny Local Government Council, Hon. Benjamin Ibietonye); the Canadian Whitehorse Mining Initiative (WMI), as could be referred to via Natural Resources Canada, 'Whitehorse Mining Initiative' < http://www.nrcan.gc.ca/miningmaterials/policy/government-canada/8698 $\square$ Accessed 7 February, 2020.

${ }^{3}$ UN, Paragraph 280 (d), 'Focused Political Outcome Document of the UNCSD (Rio+20), 2012, 'The Future We Want - Outcome Document', captioned 'Promoting Public-Private Partnerships'.

${ }^{4}$ Homepage of the UN Global Compact <https://www.unglobalcompact.org/ $\square$ UN Global Compact, 'Who We Are' $<$ https://www.unglobalcompact.org/what-is-ge $\sqsubset$; The UN Global Compact, 'The Power of Principles: The Ten Principles of the UN Global Compact' <https://www.unglobalcompact.org/what-is-gc/mission/principles $\square$ all Accessed 7 February, 2020.

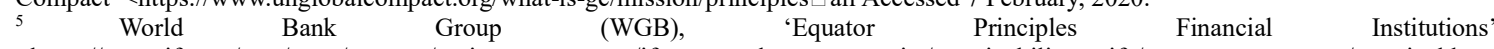

$<$ https:/www.ifc.org/wps/wcm/connect/topics_ext_content/ifc_external_corporate_site/sustainability-at-ifc/company-resources/sustainable-

finance/equator+principles+financial+institutions $\square$ Accessed 7 February, 2020

${ }^{6}$ Homepage of the Equator Principles (EPs) $<$ https://equator-principles.com $\square$ Accessed 7 February, 2020.

${ }^{7}$ Equator Principles, 'Designated Countries'<https://equator-principles.com/designated-countries/ $\square$ Accessed 20 November, 2019.
} 
for such an assessment, the EPsA requires that a country must be both a member of the Organisation for Economic Co-operation and Development (OECD) and appear on the World Bank High Income Country list, ${ }^{1}$ in order to qualify as an EPs designated country. These data sets are reviewed quarterly by the Equator Principles Secretariat, so as to ensure that any change in status of a country is reflected in the designated countries list. ${ }^{2}$

The IFC Sustainability Framework is another private sector mechanism for business sustainability and SD. This Framework consists of the (i) IFC's policy on environmental and social sustainability, which defines IFC's commitments to environmental and social sustainability; (ii) IFC's performance standards for managing environmental and social risks, which define responsibilities of IFC clients for managing their environmental and social risks; and (iii) IFC's access to information policy. ${ }^{3}$ This Framework articulates the corporation's strategic commitment to SD, as an integral part of the IFC's approach to risk management. ${ }^{4}$ It demonstrates how the IFC works with partners to establish principles for impact investing, in order to enhance financial returns for the corporation and to help its investors achieve positive impacts of their operations towards the wellbeing of society, including developing countries. ${ }^{5}$

Besides, the UN Global Compact, the IFC Sustainability Framework, and the EPs, there is another example of private sector mechanisms for business sustainability and SD. This is the World Business Council for SD (WBCSD), which promotes partnership of business organisations towards business sustainability and SD in general. Briefly put, the WBCSD, with its headquarters in Geneva, Switzerland, founded 1992, is a CEO-led organisation of about 200 of the world's forward-thinking international companies, which are spread over six continents (i.e., Europe, Asia, North America, Latin America, Middle East and Australia), and connected to 60 national and regional business councils and partner organisations, working together to make business more successful and sustainable. The Council helps its member-companies to be more successful and sustainable, by focusing on the maximum positive impacts for shareholders, the environment and societies. ${ }^{6}$

The foregoing and other forms of global and international partnership arrangements towards business sustainability and SD may be explored by governments and private sector organisations, especially governments of developing countries and private sector organisations operating in developing countries, in the process of ongoing and progressively advancing era of global efforts towards promoting strategies and other forms of initiatives to achieve SD.

It is however essential to highlight that in the course of the foregoing and other forms of partnership arrangements towards SD, the role of governance, namely good public sector governance (i.e., good political leadership [GG]), is crucial, key, compelling and inevitable. This is because no matter how well designed or intended and notwithstanding how effectively implemented, the responsibility of business (the private sector) is not an alternative to GSR embedded in GG. Otherwise put, no matter how well initiated and how successfully implemented, CSR is not an alternative to GSR ingrained in good, transparent, accountable and responsible governance (GG). ${ }^{7}$ Development and, by and large, SD are precisely, simply and squarely aspects of the traditional duties and responsibilities of government, particularly GG, as GG and SD are indivisible and thus inseparable from each other. Development (including the right to development and to secure adequate standard of living of citizens and residents in a country) and SD are domestic issues, which are principally associated with GSR, embedded in GG, the social contract of governance, and state responsibility (government responsibilities) in the domestic affairs (SRDAs). ${ }^{8}$

\footnotetext{
' World Bank Group, 'High Income - World Bank Data'<https://data.worldbank.org/income-level/high-income $\square$ Accessed 20 November, 2019. ${ }^{2}$ EPs, 'Designated Countries' <https://equator-principles.com/designated-countries/ $\square$ Accessed 20 November, 2019.

${ }^{3}$ IFC, 'IFC Sustainability Framework' < https://www.ifc.org/wps/wcm/connect/topics_ext_content/ifc_external_corporate_site/sustainabilityat-ifc/policies-standards/sustainability + framework $\square$ Accessed 20 November, 2019.

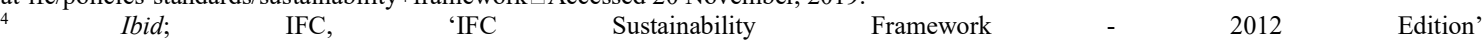

$<\mathrm{https} / /$ www.ifc.org/wps/wcm/connect/topics_ext_content/ifc_external_corporate_site/sustainability-at-ifc/policies-

standards/ifcsustainabilityframework_2012 $\square$ Accessed 20 November, 2019.

${ }^{5}$ Homepage of the IFC < https://www.ifc.org/wps/wcm/connect/corp_ext content/ifc external corporate site/home $\square$ Accessed 20 November, 2019; IFC, 'About IFC' <https://www.ifc.org/wps/wcm/connect/corp_ext_content/ifc_external_corporate_site/about+ifc_new $\square$ Accessed 20 November, 2019.

6 Homepage of the WBCSD <https://www.wbcsd.org/ ; WBCSD, 'Our philosophy of open membership' https://www.wbcsd.org/Overview/Our-members $₫$ WBCSD, 'Membership by sector: Membership by region' $<$ https://www.wbcsd.org/Overview/Our-members $\square$ all Accessed 7 February, 2020.

${ }^{7}$ Paragraphs 27 and 29, Johannesburg Declaration on SD, 2002, on the limits of CSR and the regulatory duties and responsibilities of government; E. T. Bristol-Alagbariya (2010 [23]), 16-17 and 331.

${ }^{8}$ J. Rousseau, The Social Contract (Wordsworth Classics of World Literature) (Wordsworth Editions 1998); J. Rousseau, The Social Contract or Principles of Political Right (Aziloth Books 2011); M. T. Ladan, Materials and Cases on Public International Law, (Ahmadu Bello University Press 2007), 48-50; D. Harris, Cases and Materials on International Law (Sweet and Maxwell 2011), 421; Preamble and Section 14 (2) (b), 1999 Constitution of the Federal Republic of Nigeria (CFRN [as amended]); Paragraph 8, 'Focused Political Outcome Document of the UNCSD (Rio+20), 2012, 'The Future We Want - Outcome Document', captioned 'Green Bridge Partnership Programme' towards SD; E. T. Bristol-Alagbariya (2010 [n23]), 12-13, 15-16, 28, 30-31, 33, 35, 45, 237, 330, 331 and 335; E. T. Bristol-Alagbariya (2013 [n23]).
} 


\section{Conclusion}

So far, this study has examined SD as a soft law concept of SD, which is transforming SD-oriented initiatives of the UN system into hard law instruments in member-states of the UN and promoting partnerships around the globe. In the process, it gave a background of the history of the concept of SD within the context of the UN system, based on the UN SRJR Process, its outcomes and their advancing and progressively ongoing processes.

The study uses the term 'UN SRJR Process' as an analytical tool, and explains what this term represents, the so far, successive UN Conferences on the environment and development, which are designed to promote the achievement of SD, namely the UN Conference on the Human Environment (UNCHE), held at Stockholm, Sweden, in 1972 (based on which the assembly of the world community leaders from the UN member-states took place in Nairobi, Kenya, from 10 - 18 May 1982); the UN Conference on Environment and Development (UNCED), held at Rio de Janeiro, Brazil, in 1992; the World Summit on SD (WSSD), held at Johannesburg, South Africa, in 2002; and the Conference on Sustainable Development (UNCSD [Rio+20]), held again in Rio de Janeiro, Brazil, in 2012. The study thus refers to these UN Conferences as the UN SRJR Conferences.

The study also considered the features of SD and various SD-oriented initiatives and underscored the wellbeing of humans and overall nature on Planet Earth as the principal focal issues of ongoing, progressive and increasingly advancing global efforts, being spearheaded and championed by the UN, to foster, promote and achieve SD.

The study further considered soft-law SD-oriented mechanisms of the UN system and others which are distinct from those of the UN system, namely the SRJR Process and its ongoing processes, such as the UN Global Compact. In this regard, some SD-oriented soft law partnership mechanisms, designed towards business sustainability and generic SD, such as the IFC sustainability framework, the Equator Principles (EPs) and the WBCSD. The study highlights that these and other forms of global and international partnership arrangements towards business sustainability and all-embracing SD may be explored by governments and the private sector, especially governments of developing countries and private sector business organisations operating in developing countries, in the process of ongoing efforts to achieve SD.

The study arrives at the finding that increasingly, aspects of the_soft law concept, principle, theory and regulatory practice of SD are increasingly being backed by law in sovereign states, in the course of transforming SD-oriented initiatives of the UN system into hard law instruments in the said states (which are member-states of the UN) and that initiatives towards SD are generating various forms of SD-oriented partnership arrangements around the globe. Accordingly, it is the finding of the study that SD-oriented soft law mechanisms are increasingly having the compelling force and effects of hard laws in sovereign states, especially developing countries, and in particular, resources-rich developing countries, and thereby transforming developmental PPPs associated with the environment, towards GEG and thus promoting GG and SD, towards a fairer, kinder, more just, sustainable and peaceful world.

The study therefore concludes that SD is a peculiar soft law concept, principle, rule, theory and regulatory practice, which is transforming SD-oriented initiatives into hard law instruments in sovereign states, towards fostering, promoting and enhancing the wellbeing of humanity, the environment and overall nature on Planet Earth.

By and large, this study reveals the key significance of public sector governance, especially GG and its inevitable roles and responsibility towards SD, while echoing further that GG and SD are indivisible and inseparable. In this regard, the need for GSR embedded in GG occupies a central and pivotal place. Thus, regarding corporate responsibility (CSR) framework, which includes corporate environmental and social responsibilities, the study arrives at the finding that no matter how well designed or intended and notwithstanding how effectively implemented, CSR is not an alternative to GSR, embedded in GG. Put differently, no matter how well initiated and how successfully implemented, CSR is not an alternative to GSR, ingrained in good, transparent, accountable and responsible governance (GG). The study highlights that development and thus SD, towards the wellbeing of the environment, humans and other resources of nature, are domestic issues, which are primarily and principally associated with GSR, ingrained in GG, the social contract of governance and state responsibility (government responsibilities) in the domestic affairs (SRDAs).

This study is thus a clarion call on governments of sovereign states around the world, especially those of developing countries, to be alive and awake to fulfil their responsibilities to their citizens, country, humanity and the global community on Planet Earth, by offering good, transparent, accountable and responsible governance in the ongoing global march to achieve SD.

The study also demonstrates and thus echoes the fact that development partnerships, designed to promote and enhance SD and sustainability, are crucial, key, compelling and inevitable in the ongoing global efforts towards SD. It recommends that governments, organisations and peoples of the world should, while strengthening existing SD-oriented partnerships, endeavour to enter into more and more of such partnership arrangements, to promote SD. Such partnerships could be world-wide, as those entered under the auspices of the UN; they could also be between and among entities of the Global South-South and the Global North-South partnership arrangements, as well as partnerships among regional groups and even bilateral partnerships as well as Public Private Sector 
Partnerships (PPSPs) between host governments of developing countries, advanced countries, developmental agencies in advanced countries and multinational companies (MNCs), for various forms of developmental and SD-oriented plans, policies and programmes (including projects (PPPs) in developing countries.

\section{References}

Abbott K. W. and Snidal D., 'Hard and Soft Law in International Governance' [2000] 54 (3) International Organization, 421456.

Allen R., How to Save the World: Strategy for World Conservation (Corgi Children's 1982).

Ansell C. and Torfing J. (eds), Handbook on Theories of Governance (Edward Elgar Publishing 2016).

Ayre G. and Callway R. (eds), Governance for Sustainable Development: A Foundation for the Future (Earthscan 2005).

Bartelmus P., Sustaining Prosperity, Nature and Wellbeing; What Do the Indicators Tell Us? (Routledge 2018).

Baxter R. R., 'International Law in 'Her Infinite Variety' [1980] 29 (4) International and Comparative Law Quarterly, 549 566.

Bell S. and Morse S., Sustainability Indicators: Measuring the Immeasurable? (Earthscan 2008).

Bristol-Alagbariya E. T., 'Environmental Assessment Law towards Sustainable Development in Nigeria and the New Partnership for Africa's Development Action Plan for the Environment Initiative' [2016] Environmental \& Planning Law Review (ELPR), 13 (1-2), 2016, 1294.

Bristol-Alagbariya E. T., Governance Towards Sustainable Development in Nigeria: The Role of Strategic Assessment of Decisions \& Actions (Centre for Energy, Petroleum \& Mineral Law \& Policy [CEPMLP]/Dundee University Press [DUP] 2013), xxxvii-xxxviii, 46-49 and 272-393.

Bristol-Alagbariya E. T., Participation in Petroleum Development: Towards Sustainable Community Development in the Niger Delta (CEPMLP/DUP 2010), 12-13, 15-17, 28, 30-31, 33, 35, 45, 149, 75-82, 147, 237, 318, 330 - 331 and 327-338.

Bristol-Alagbariya E. T., Petroleum Development \& the Environment in Rivers State Nigeria: Fallouts of the UNEP Report on Ogoniland, Environmental Regulatory Standards \& Sustainable Development Laws \& Practices (LAP LAMBERT Academic Publishing 2018), 1, 6, 43, 66 and 74.

Carew-Reid J., Prescott-Allen R., Bass S. and Dalal-Clayton B., Strategies for National Sustainable Development (Sustainable Development Set) (Earthscan 2009).

Clark H., The Importance of Governance for Sustainable Development (The Institute of Southeast Asian Studies [ISEAS] Publishing 2012)

Corcoran P. B. (ed), The Earth Charter in Action: Toward a Sustainable (KIT Publishers 2006).

Dasgupta P., Human Well-Being and the Natural Environment (Oxford University Press 2004).

Decleris M., The Law of Sustainable Development: General Principles: A Report of the European Commission (European Commission 2000).

Department of Environment, Food and Rural Affairs (DEFRA) UK, Sustainable Development Indicators July 2013 (The National Archives/Sustainable Development Statistics 2013).

Department for Environment, Food and Rural Affairs (DEFRA), UK, Sustainable Development Indicators in Your Pocket 2009: An Update of the UK Government Strategy Indicators, (DEFRA 2009), 119-120.

Dodge R., Daly A. P., Huyton J. and Sanders L. D., R. Dodge et al, 'The Challenge of Defining Wellbeing' [2012] 2 (3) International Journal of Wellbeing, 222-235.

Edoh T. and Wuam T. (eds), Democracy, Leadership And Accountability in Post-Colonial Africa: Challenges And Possibilities: Essays in Honour of Professor Akase Paul Sorkaa (Aboki Publishers 2009).

Estes R. J. and Sirgy M. J. (eds) The Pursuit of Human Well-Being: The Untold Global History (International Handbooks of Quality-of-Life) (Springer International Publishing 2017).

Esty D. C. (ed), A Better Planet: 40 Big Ideas for a Sustainable Future (Yale University Press 2019).

Etemire U., 'Reflections on the Role of International Custom and Soft Law in Environmental Protection' [2016] 1 (1) UNIPORT Journal of Public Law, 60-61.

Federal Environmental Protection Agency (FEPA), National Policy on the Environment (FEPA 1999) 1.

FEPA, Nigeria's National Agenda 21 (FEPA 1999).

Filho W. L., Pociovalisteanu D. and Al-Amin A. Q.(eds), Sustainable Economic Development: Green Economy and Green Growth (Springer International Publishing 2017).

Friedrich J., International Environmental "Soft Law": The Functions and Limits of Nonbinding Instruments in International Environmental Governance and Law (Springer Heidelberg 2013).

Ginther, K., Denters, E. and de Waart, P. J. I. M. (eds), Sustainable Development and Good Governance (Martinus Nijhoff Publishers 1995).

Guzman A. T. and Meyer T. L., 'International Soft Law' [2010] 2 (1) The Journal of Legal Analysis, 171-225.

Haocai L. and Gongde S., Soft Law Governance: Towards an Integrated Approach (William S. Hein \& Co 2013).

Harris D., Cases and Materials on International Law (Sweet and Maxwell 2011), 421.

Hynes W. and Wang S., Green Growth and Developing Countries: A Summary for Policy Makers (The Organisation for Economic Co-operation and Development [OECD] 2012).

Kirton J. J. and Trebilcock M. J. (eds), Hard Choices, Soft Law: Voluntary Standards in Global Trade, Environment and Social Governance (Global Environmental Governance Series) (Routledge 2016).

International Institute for Environment and Development (IIED) and World Business Council for Sustainable Development (WBCSD), Breaking New Ground: Mining, Minerals, and Sustainable Development: The Report of the MMSD Project (Earthscan 2002).

The International Union for Conservation of Nature (i.e., IUCN, the World Conservation Union), United Nations Environment 
Programme (UNEP) and the World Wildlife Fund (WWF), World Conservation Strategy: Living Resources Conservation for Sustainable Development (IUCN 1980).

IUCN, UNEP and World Wide Fund for Nature (WWF), Caring for the Earth: 5 (Sustainable Development Set) (Earthscan 2009).

Jackson T., Prosperity without Growth: Economics for a Finite Planet (Earthscan 2011).

Jackson T., Prosperity without Growth?: The Transition to a Sustainable Economy (Sustainable Development Commission 2009).

Kallhauge A. C., Sjostedt G. and Corell E. (eds), Global Challenges: Furthering the Multilateral Process for Sustainable Development (Greenleaf Publishing 2005).

Ladan M. T., Materials and Cases on Public International Law, (Ahmadu Bello University Press 2007), 48-50.

Lagoutte S., Gammeltoft-Hansen and Cerone J. (eds), Tracing the Roles of Soft Law in Human Rights (Oxford University Press 2016).

Lueddeke G. R., Survival: One Health, One Planet, One Future (Routledge Studies in Sustainability) (Routledge 2019).

Mc Gillivray M. and Clarke M., Understanding Human Well-Being (Bookwell Publications 2007).

Millennium Ecosystem Assessment, Ecosystems and Human Well-Being: A Framework for Assessment (Millennium Ecosystem Assessment Series) (Island Press 2003).

Millennium Ecosystem Assessment, Ecosystems and Human Well-Being: Synthesis Report (Millennium Ecosystem Assessment Series) (Island Press 2005).

Munro D. A., Caring for the Earth: A Strategy for Sustainable Living (Union Internationale pour la Conservation de la Nature et de ses Ressources, Switzerland 1994).

Najam A., Papa M. And Taiyab N., Global Environmental Governance: A Reform Agenda (International Institute for Sustainable Development (IISD) 2006).

Okogbule N. S., Legal Status of Economic Development Agreements (Davis Printing \& Packaging Co. 2004).

Prescott-Allen R, The Wellbeing of Nations: A Country-by-Country Index of Quality of Life and the Environment (Island Press 2001).

Puppim de Oliveira J. A., (ed), Green Economy and Good Governance for Sustainable Development: Opportunities, Promises and Concerns (UN University Press 2012).

Rexler J., 'Beyond the Oil Curse: Shell, State Power, and Environmental Regulation in the Niger Delta' [2010] 12 (1) Stanford Journal of International Relations, 26-31.

Ross A., Sustainable Development Law in the UK: From Rhetoric to Reality? (Earthscan 2012).

Rousseau J., The Social Contract or Principles of Political Right (Aziloth Books 2011).

Rousseau J., The Social Contract (Wordsworth Classics of World Literature) (Wordsworth Editions 1998).

Sachs J. F., The Age of Sustainable Development (University of Columbia Press 2015).

Segger M. C. and Khalfan A., Sustainable Development Law: Principles, Practices, \& Prospects (Oxford University Press 2005).

Shelton D., Commitment and Compliance: The Role of Non-binding Norms in the International Legal System (Oxford University Press 2003).

Skjærseth J. B., Stokke O. S. and Wettestad J., 'Soft Law, Hard Law, and Effective Implementation of International Environmental Norms' [2006] 6 (3) Global Environmental Politics, 104-120.

UN Association of Australia (UNAA), The Earth Charter (UNAA 2017).

UN Department on Economic and Social Affairs (UNDESA), Indicators of Sustainable Development: Guidelines and Methodologies (UN 2007).

UN Environment Programme (UNEP), Environmental Assessment of Ogoniland (UNEP 2011).

UN Environment Programme (UNEP), Healthy Environment, Healthy People (UNEP 2016).

Weeks G., Soft Law and Public Authorities: Remedies and Reform (Hart Publishing 2016).

Westerman P., Hage J., Kirste S. and Mackor A. R. (eds), Legal Validity and Soft Law (Springer International Publishing AG 2018).

The World Commission on Environment and Development (WCED), Our Common Future (Oxford University Press 1987), x23,40 and 43.

Wuam T. and Sunday T. N. (eds), Governance and Economic Development in the Fourth Republic (Aboki Publishers 2010). 